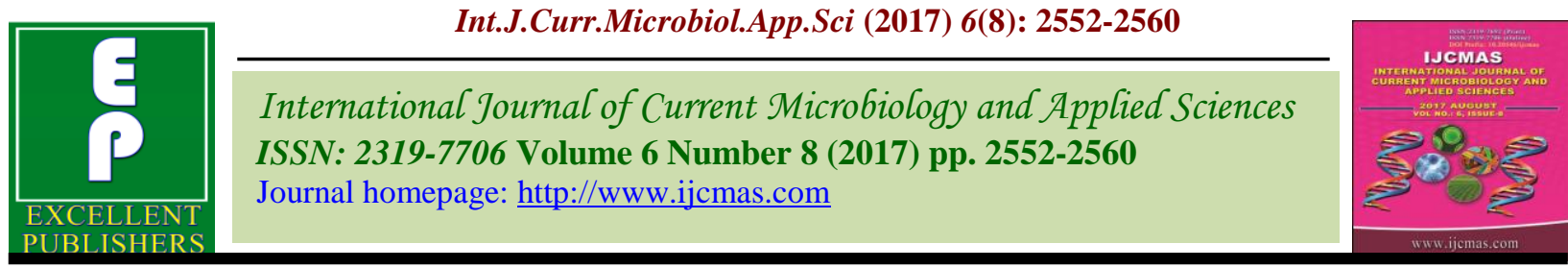

Original Research Article

https://doi.org/10.20546/ijcmas.2017.608.302

\title{
Studies on Bio-Chemical Changes in Wood Apple (Limonia acidissima L.) Fruits during Growth and Development
}

\author{
Awadhesh Kumar* and Bhagwan Deen \\ Department of Horticulture, College of Horticulture and Forestry, Narendra Deva University of \\ Agriculture and Technology Kumarganj Faizabad (UP)-224 229, India \\ *Corresponding author
}

\begin{tabular}{|l|}
\hline Keyw or d s \\
Wood apple, \\
Chemical \\
changes, Growth \\
and development, \\
Maturity index. \\
\hline Article Info \\
\hline $\begin{array}{l}\text { Accepted: } \\
\text { 21 June 2017 } \\
\text { Available Online: } \\
\text { 10 August } 2017\end{array}$ \\
\hline
\end{tabular}

A B S T R A C T

The experiment was conducted to changes in wood apple fruits during growth and development and determination of the maturity index were studied at Department of Horticulture, Narendra Deva University of Agriculture and Technology Kumarganj Faizabad during the year 20122013. The observations were recorded from fruiting to maturity and ripening time of fruits at 30 days intervals. The mature fruits of wood apple had $20.60 \%$ TSS, $4.10 \%$ titratable acidity and TSS: acid ratio 5.02 contents. These parameters can be used as maturity index for wood apple fruits. A fully ripe fruit contains $21.70 \%$ TSS, $3.80 \%$ titratable acidity, 6.82 $\mathrm{mg} / 100 \mathrm{~g}$ ascorbic acid and $19.83 \%$ total sugars. The TSS, TSS: acid ratio, ascorbic acid, reducing, non-reducing and total sugars contents were increased, whereas, total phenol content continuously decreased during growth and development of wood apple fruits. The titratable acidity and pectin content also increased up to maturity and thereafter, it were decreased.

\section{Introduction}

Wood apple (Limonia acidissima L.) is underutilized, former and indigenous fruit plants. It is also known by different names such as kainth, elephant apple, and monkey fruit. It is one of the very hardy fruit crops found all over the plains of Southern Maharashtra, West Bengal, Uttar Pradesh, Chhattisgarh and Madhya Pradesh. The wood apple is not under regular orcharding, however, along the border of fields, roads, railway lines and as a roadside tree, near villages and banks of the river are the common places where the plants are found as stray plant. Wood apple is a small to moderate size, deciduous, glabrous tree with thorny branches reaching to a height of 10 metres with 0.6 metres to 1.6 meters girth (Troup, 1921).

The fruit tree can be grown even on saline, waste and neglected lands normally unsuitable for cultivation of other fruit trees. The tree also flourishes well in dry areas and is not affected by any serious pests or diseases due to its resistant nature to both biotic and abiotic stresses. 
The fruits are consumed as a good source of juice during its harvesting season due to their low cost and thirst quenching ability. A homemade drink popularly known as "Sarbat" is prepared from the wood apple fruits. The wood apple pulp is a rich source of Beta carotene, a precursor of vitamin-A which also contains significant amount of vitamins$\mathrm{B}$ such as riboflavin and thiamine and it had small quantities of ascorbic acid content (Poongodi et al., 2013). Fruits have high medicinal value and used in India as a liver and cardiac tonic while unripe fruits are used as an astringent means of treating diarrhea and dysentery in folk medicines. It is effective treatment for hiccough, sore throat and diseases of the gums. The fruit is also used for curative properties, which makes it is one of the useful medicinal plants of India. Geda and Bokadia (1980) reported antimicrobial activity of essential oil extracted from wood apple fruits and noticed its effectiveness against 12 human pathogenic bacteria. Maiti and Mishra (2000) also reported presence of antivenom activity in wood apple fruits.

Juice of young leaves is mixed with milk and sugar and given as a remedy for biliousness and intestinal troubles of children. Saima et al., (2000) isolated an acidic heteropolysaccharide from wood apple fruits which showed significant in-vivo Ehrlich ascites carcinoma cell growth inhibition. The flesh of the mature fruits blended with cardamom, honey and cumin seeds are efficacious for indigestion, diarrhea and piles.

Fruits are very well known for their medicinal properties due to its high nutritive value. Every part of wood apple plant like leaves, bark, roots, and fruit pulp are used against snakebite. Seeja et al., (2005) justified use of wood apple fruits by tribal people as a substitute for bael (Aegle marmelos Correa.) and vice versa due to the similar composition of leaf extracts to some extent.
The average chemical composition like TSS ranges from 10.67 to $14.33^{\circ}$ Brix, acidity 1.04- $4.50 \%$ and total sugars 4.08-4.47\% (Hiwale, 2006). According to Shukla and Singh (2008) wood apple fruit TSS ranged 9.40-16.00 ${ }^{0}$ Brix, acidity from 0.83 to 2.76 $\%$, vitamin-C from 1.68 to $3.40 \mathrm{mg} / 100 \mathrm{~g}$ pulp and total sugars from 3.46 to $5.64 \%$ in different accessions. The nutritional and chemical properties of fresh wood apple fruits showed that it contains $6.3 \mathrm{~g}$ protein, $15.6 \mathrm{~g}$ total carbohydrates, $72 \%$ moisture, $4.16 \%$ titratable acidity, $2.6 \mathrm{mg} / 100 \mathrm{~g}$ vitamin-C, 235 $\mathrm{mg} / 100 \mathrm{~g}$ total phenol and $1412.55 \mu \mathrm{g} / \mathrm{g}$ total antioxidant capacity (Poongodi et al., 2013). Immature fruits are more acidic astringent in taste, starchy and hard texture. After ripening fruits become soft in flesh and decreases the acidity and astringency in taste and increases the flavour. It is a climacteric fruit, ripening may also takes place after fruit harvest. It is well known the fruit quality and storage life of fruits, which avoiding the waste of raw material. The information pertaining to the biochemical changes in wood apple fruit during growth and development is very scanty. Fruit harvesting at appropriate maturity stage is an important factor affecting fruit quality as well as quality changes during period of post-harvest handling. Therefore, the objective of this work was to determine the appropriate maturity and harvesting time of wood apple fruits in India.

\section{Materials and Methods}

The present experiment was carried out at post graduate laboratory of Department of Horticulture College of Horticulture and Forestry, Narendra Deva University of Agriculture and Technology, Kumarganj, Faizabad Uttar Pradesh. The university was geographically located at $26.47^{\circ} \mathrm{N}$ latitude, $82.12^{\circ} \mathrm{E}$ longitude and at 113.0 metres altitude. The location falls under IndoGangetic plains of North India. In the present 
investigation wood apple fruits were collected from Ratapur village of Milkipur Tehsil, Faizabad. The 15-20 year old plants of wood apple were selected for this investigation and fruits were harvested by hands to avoid cracking during August, 2012 to March, 2013 as and when required as per study schedule.

\section{Total soluble solids}

Total soluble solids were determined by hand refractometer (ERMA made) of $0-32 \% \%$ ranges at room temperature. The reading was corrected at $20^{\circ} \mathrm{C}$ (Ranganna, 2010) and the mean value was expressed as per cent total soluble solids content in the sample.

\section{Titratable acidity}

The total titratable acidity present in sample was ascertained by titration of samples against $\mathrm{NaOH}$ solution. Then $5 \mathrm{~mL}$ aliquot was taken and titrated against $0.1 \mathrm{~N}$ sodium hydroxide standard solution using 2-3 drops phenolphthalein as an indicator (Ranganna, 2010).

\section{TSS: acid ratio}

The TSS was divided by titratable acidity of the sample to find out the TSS: acid ratio.

\section{Ascorbic acid}

Five $5 \mathrm{~g}$ of fruit sample was macerated with $15 \mathrm{~mL}$ of $3 \% \mathrm{HPO}_{3}$ (metaphasphoric acid) solution. Then samples were filtered through muslin cloth in to $50 \mathrm{~mL}$ volumetric flask and volume was made up with $3 \% \mathrm{HPO}_{3}$ solution.

The $5 \mathrm{~mL}$ aliquot was taken from volumetric flask and titrated against 2, 6-dichlorophenolindophenol dye solution (AOAC, 2012). The end point was marked by appearance of light pink colour. The determination procedure was followed as described by (Ranganna, 2010).

\section{Sugars}

The Fehling's ' $A$ ' and ' $B$ ' solutions (Lane and Eynon, 1923) were used to estimate the sugars content in sample and the procedure as suggested by Ranganna, 2010. Sugars were calculated and expressed in per cent.

\section{Total phenols}

The total phenols were ascertained by the method of Swine and Hills (1959). One g of fruit sample was crushed with the help of pestle and mortar and the volume was made up to $20 \mathrm{~mL}$ with $80 \%$ ethanol alcohol. Thereafter, $15 \mathrm{~mL}$ extract were taken and centrifuged at $1000 \mathrm{rpm}$ for 10 minutes. Clear extract was taken and residue was discarded. $1.0 \mathrm{~mL}$ clear extract, $1.0 \mathrm{~mL}$ phenol reagent (2 $\mathrm{N}$ folin-Ciocalteau) and $2.0 \mathrm{~mL}$ sodium carbonate solution $(20 \%)$ were mixed together and shaken well then final volume was made up to $50 \mathrm{~mL}$ with distilled water. Blue colour developed in an hour that was stable for many hours. The optical density (OD) was measured at $765 \mathrm{~nm}$ by ELICO made spectrophotometer model SL 160.

\section{Pectin}

To estimate total pectic substances as calcium pectate, $50 \mathrm{~g}$ of sample were taken in to 1000 $\mathrm{mL}$ of beaker containing $400 \mathrm{~mL}$ of $0.05 \mathrm{~N}$ HCL. Thereafter, sample was heated at 80$90^{\circ} \mathrm{C}$ for 2 hours, thereafter, left for cooling then sample was transferred in to $500 \mathrm{~mL}$ volumetric flask and volume was made up with distilled water. The sample shook and extract were filtered through Whatman filter paper No 4 grade in to $500 \mathrm{~mL}$ conical flask. The $100 \mathrm{~mL}$ aliquot was taken in $1000 \mathrm{~mL}$ of beaker and $250 \mathrm{~mL}$ water were added and then sample was neutralized with $1 \mathrm{~N} \mathrm{NaOH}$ and $10 \mathrm{~mL} 1 \mathrm{~N} \mathrm{NaOH}$ were added in excess and allowed to stand overnight. Next day, the $50 \mathrm{~mL} 1 \mathrm{~N}$ acetic acid were added and after 5 
minutes $25 \mathrm{~mL} 1 \mathrm{~N}$ calcium chloride were also added with stirring. After 1 hour sample was boiled for 1-2 minutes and filtered through previously prepared filtered paper and washed with water to make free from chlorides. The filter paper along with calcium pectate precipitate was dried in oven at $100^{\circ} \mathrm{C}$ for overnight, cooled and weighed. The result was expressed in per cent calcium pectate (Ranganna, 2010).

\section{Statistical Analysis}

The data were analyzed using completely randomized design (CRD) of analysis of variance with three replications as described by Panse and Sukhatme (1985).

\section{Results and Discussion}

\section{Total soluble solids}

Data regarding to total soluble solids were continuously increased with its growth and development (Table 1). The increase in total soluble solids content might be due to depolymerisation of polysaccharides and conversion of fruit starch to sugars, and also synthesis of other water solubles solids. Kaushik et al., (2002) also reported that TSS content of bael fruits increased continuously with growth and development. Similar trend in increasing of TSS in sapota fruits were observed by Paralkar et al., (1987), in loquat by Ulchino et al., (1994) and in guava by Patel et al., (2015). There reports are conformity to the present result in which wood apple fruits total soluble solids content increased continuously during growth and development.

\section{Titratable acidity}

Observations presented in table 1 , revealed that the titratable acidity content of wood apple fruits was increased up to 180 days after fruit setting, then it showed continuous decreasing trend till ripening. The increase in titratable acidity content might be due to increased bio-synthesis of organic acids during initial period of fruit growth. The decrease in titratable acidity at later stage of growth during ripening was could be due to rapid utilization of organic acid and conversion of organic acids in to their salts and sugars (Ruffner et al., 1975). Mattoo et al., (1975) reported that non-volatile organic acids are among the major cellular constituents undergoing changes during fruit ripening. The results of present study are in agreement with those reported by Pal (1993) in phalsa, Dhillon et al., (2007) in pear and Patel et al., (2015) in guava fruits that the titratable acidity content was gradually increased up to maturity stage, and thereafter, it was decreased with ripening stage.

\section{TSS: acid ratio}

Data on TSS: acidity ratio was increased with growth and development up to ripening of wood apple fruits (Table 1). The increase in TSS: acidity ratio with growth and development of fruits might be due to increasing in total soluble solids and decrease in acidity content in fruit. The findings of Randhawa et al., (1964) in Marsh Seedless and pink verities of grape fruits, Kundu et al., (1998) and Singh et al., (2004) in banana and Patel et al., (2015) in guava fruits also support the contention that TSS: acidity ratio was increased throughout growth and development period of wood apple fruits.

\section{Ascorbic acid}

In present findings the accumulation pattern of ascorbic acid content of wood apple fruits showed an increasing trend (Table 3) with growth and development. The gradual increase in ascorbic acid content during growth and development of fruits might be 
due to accumulation and greater synthesis of glucose-6- phosphate, which served as a precursor for ascorbic acid synthesis in fruits (Mapson, 1970). Similar, increasing trend in ascorbic acid content during growth and development has been reported in phalsa (Singh and Acharya, 1999) and in bael fruits (Kumar and Deen 2015).

\section{Reducing sugars}

It is clear from table 2, that reducing sugars were increased continuously. The reducing sugars content in wood apple fruits were increased with growth and development. The increasing in reducing sugars content of fruits might be due to conversion of polysaccharides in to sugars during growth and development. The earlier reports regarding increase in reducing sugars with growth and development of wood apple fruits are not available. However, present results are supported by the findings of Paralkar et al., (1987) in sapota fruits, Dutta and Dhua (2004) in mango fruits and Aly et al., (2013) in guava fruits.

Table.1 Changes in TSS, acidity and TSS/acid ratio of wood apple fruit During growth and development

\begin{tabular}{|c|c|c|c|}
\hline Interval (Days) & TSS (\%) & Acidity (\%) & TSS/ Acid ratio \\
\hline 30 & 9.45 & 1.98 & 4.77 \\
\hline 60 & 11.85 & 2.46 & 4.81 \\
\hline 90 & 14.10 & 2.90 & 4.86 \\
\hline 120 & 16.50 & 3.35 & 4.92 \\
\hline 150 & 18.85 & 3.80 & 4.96 \\
\hline 180 & 20.60 & 4.10 & 5.02 \\
\hline 210 & 21.30 & 3.95 & 5.39 \\
\hline 240 & 21.70 & 3.80 & 5.71 \\
\hline SEm \pm & 0.48 & 0.39 & 0.58 \\
\hline CD at 5\% & 1.05 & 0.86 & 1.28 \\
\hline
\end{tabular}

Table.2 Changes in reducing sugars, non-reducing sugar and total sugars content of wood apple Fruit during growth and development

\begin{tabular}{|c|c|c|c|}
\hline Interval (Days) & Reducing sugars (\%) & Non-reducing sugar (\%) & Total sugars (\%) \\
\hline 30 & 2.30 & 5.65 & 7.95 \\
\hline 60 & 2.63 & 6.62 & 9.25 \\
\hline 90 & 2.99 & 8.95 & 11.94 \\
\hline 120 & 3.59 & 10.70 & 14.29 \\
\hline 150 & 4.32 & 12.23 & 16.55 \\
\hline 180 & 4.87 & 13.48 & 18.35 \\
\hline 210 & 5.43 & 13.57 & 19.00 \\
\hline 240 & 6.03 & 13.80 & 19.83 \\
\hline SEm \pm & 0.48 & 0.61 & 0.68 \\
\hline CD at 5\% & 1.06 & 1.34 & 1.51 \\
\hline
\end{tabular}


Table.3 Changes in ascorbic acid, total phenol and pectin content of wood apple fruit during Growth and development

\begin{tabular}{|c|c|c|c|}
\hline Interval (Days) & Ascorbic acid (mg/100g) & Total phenol (mg/100g) & Pectin (\%) \\
\hline 30 & 3.86 & 221.50 & 1.22 \\
\hline 60 & 4.11 & 218.20 & 1.60 \\
\hline 90 & 4.47 & 210.40 & 2.10 \\
\hline 120 & 5.02 & 192.10 & 2.65 \\
\hline 150 & 5.45 & 167.40 & 2.90 \\
\hline 180 & 5.96 & 122.10 & 3.15 \\
\hline 210 & 6.48 & 103.20 & 1.70 \\
\hline 240 & 6.82 & 80.10 & 1.30 \\
\hline SEm \pm & 0.55 & 4.62 & 0.37 \\
\hline CD at 5\% & 1.20 & 10.17 & 0.81 \\
\hline
\end{tabular}

\section{Non-reducing sugar}

Data presented in table 2, with respect to the non-reducing sugar content in wood apple fruits continuously increased throughout entire period of study. The tendency of increment in non-reducing sugar during growth and development might be due to availability of starch to hydrolyze in to sugars. The findings are in agreement with Paralkar et al., (1987) who reported continuous increasing trend in non-reducing sugar content of sapota. The results of present study are also in agreement with those reported by Aly et al., (2013) in guava and Kumar and Deen (2015) in bael fruits.

\section{Total sugars}

The total sugars content of wood apple fruits were increased continuously during growth and development (Table 2). An increase in simple sugars gives sweetness, decreases in organic acids and phenolics content to minimize astringency and acidity, and increases in volatile emanation to give the characteristic flavour of a fruit (Mattoo, et al., 1975). The increasing in total sugars might be because of increasing in total soluble solids, reducing and non-reducing sugars resulting from the conversion of starch in to sugars. In conformity of this findings, similar results have been reported by Oshund and Davenport (1983) in carambola, Paralkar et al., (1987) in sapota, Ghanta et al., (1994) in papaya and Aly et al., (2013) in guava fruits.

\section{Total phenol}

As per observation of the present study the total phenols content of wood apple fruit was decreased continuously during growth and development of fruit (Table 3). The decrease in total phenols content was due to reduction in tannins with increase in sugar synthesis and the diminishing of original acid taste of fruits as recorded in the present investigation.

The decrease in astringency in fruits during ripening was found to be associated with the increase polymerization of leucoanthocyanidins and hydrolysis of the astringent arabinose ester of hexahydrodiphenic acid (Misra and Swshadri, 1968). The decrease in bitterness during papaya was due to decline in phenol content (Tan and Lam, 1985). The phenolic compound was decreased in banana fruit aged on the plant (Chang et al., 1990). These are in affirmation with the earlier worker of AbuGoukh et al., (2011) in 'Galia' cantaloupes fruits and Kumar and Deen (2015) in bael fruits. Phenolic constituents are responsible for the astringent taste in unripe fruits. 


\section{Pectin}

In present study clearly indicated (Table 3) that pectin content of wood apple fruits increased up to maturity on 180 days, and thereafter, its content was decreased with ripening of fruits. This may possibly be due to the conversion of protopectin in to pectin which might have increased the total pectin content at maturity stage. An increase in pectin has also been reported by Medhi and Singh (1981) in grapes. Zablackis et al., (1995) reported that pectin content varied depending on environment, tissue and species. The contention of pectin content in fruits during growth and development also depends on type of fruits. These reports are in support of present result on pectin content of wood apple.

Based on these findings the changes which could be taken as the basic criteria for judging the maturity indices of wood apple fruits are days from fruit set to harvesting (180 days), TSS $(20.60 \%)$, titratable acidity (4.10\%), and TSS/ acid ratio (5.02) for optimum quality of fruits. A fully ripe fruit contained $21.70 \%$ TSS, $3.80 \%$ titratable acidity, $5.71 \mathrm{TSS} /$ acid ratio, $6.82 \mathrm{mg} / 100 \mathrm{~g}$ ascorbic acid and 19.83 $\%$ total sugars.

\section{Acknowledgement}

We are thankful to the University Grant Commission for funding the financial support by Rajiv Gandhi National Fellowship during this investigation.

\section{References}

Abu-Goukh, A.B.A., Baraka, A.F.M. and AliElballa, M.M. 2011. Physico-chemical changes during growth and development of 'Galia' cantaloupes. II. Chemical changes. Agri. and Bio. J. of North Ameri., 2(6): 952-963.
Aly, W., Zaki, A. and Sisy, El. 2013. Evaluation of some genotypes of guava trees grown under Alexandria Governorate Condition IIcompositional changes during ripening. World Appl. Sci. J., 28(6) 750-758.

A.O.A.C., 2012. Official Methods of Analysis of AOAC International, $19^{\text {th }}$ edition, AOAC International, Gaithersburg, MD, USA.

Chang, W.H., Hwang, Y.J. and Wei, T.C. 1990. Chemical composition and enzyme activity of Taiwan Northern banana fruit of different maturity and harvested in different seasons. Act. Horti, 275(5): 621-629.

Datta, P. and Dhua, R.S. 2004. A study on Physico-chemical changes during growth, maturity \& ripening of mango cultivar Safdar Pasand. South Ind. of Horti, 52(1/6): 297-301.

Geda, A. and Bokadia, M.M. 1980. Antimicrobial activity of essential oils on human pathogenic bacteria. Sci. and Cul, 46(1): 33-35.

Ghanta, P.K., Dhua, R.S. and Mitra, S.K. 1994. Studies on fruit growth and development of papaya $\mathrm{cv}$. Washington. Ind. J. of Horti, 51: 246-250.

Hiwale, S. S. 2006. Advances in Arid Horticulture. In: Wood apple, Saroj, P. L. and Awasthi, O.P. (Ed.). Inter. Book Distri. Co., Lkw, 2: 438-439.

Kaushik, R.A., Yamdagni, R. and Dhawan, S.S. 2002. Seasonal changes during growth and development of bael (Aegle marmelos Correa) fruit. Haryana J. of Horti. Sci., 31(1/2): 32-34.

Kumar, S. and Deen, B. 2015. Changes in chemical parameters of bael [Aegle marmelos (L.) Correa] fruits of different cultivars during growth and development. Ind. J. of Arid Horti, 9(4): 96-99.

Kundu, S., Mitra, S. and Mitra, S.K. 1998. Fruit growth and maturity of five guava 
cultivars. The Horti. J., 11(2): 91-96.

Lane, J.H. and Eynon, L. 1923. Determination of reducing sugars by Fehling Solution with Methylene blue as an indicator. $J$. of the Soci. of Chemi. Indus. London, 42: 37-7.

Maiti, S. and Mishra, T. K. 2000. Anti-venom drugs of Santals, Savars and Mahatos of Midnapore district of west Bengal, India. Ethnobotany, 12: 77-78.

Mapson, L.W. 1970. In biochemistry of fruits and their products. In: Vitamins in fruits. Hulme, A. C. (Ed.). Academic Press, London and New York, 1: 369.

Matto, A.K., Murata, T., Pantastico, Er.B, Chachin, K., Ogata, K. and Phan, C.T. 1975. In Post-harvest Physiology, Handling and Utilization of Tropical and Subtropical Fruits and Vegetables. In: Chemical changes during ripening and senescence. Pantastico, Er. B. (Ed.) Avi Publication Conecticut USA, 103127.

Medhi, G. and Singh, I.S. 1981. Studies on preharvest physiology of Beauty Seedless grapes (Vitis vinifera L.). In: Advances in Fruit Development. Punjab Agriculture University, Ludhiana, 1416.

Misra, K. and Swshadri, T.R. 1968. Chemical components of the fruit of Psidium guajava L. Phytochemistry. 7: 641-645.

Oshund, C.R. and Davenport, T.L. 1983. Ethylene and carbon dioxide in ripening fruit of Averrhoa carambola L. Horti. Sci., 18: 229-230.

Pal, D.K. 1993. Studies on biochemical changes associated with growth, development and ripening of phalsa (Grewia subinequalis L.) fruit. In: Jubilee Symposium on Horticultural Research changing Scenario, Bangalore, 17(4): 330.

Panse, V.G. and Sukhatme, P.V. 1985. Statistical methods for agricultural workers $5^{\text {th }}$ Ed. ICAR, New Delhi, 147-
157.

Paralkar, P.S., Joshi, G.D. and Salvi, M.J. 1987. Studies on Physico-chemical changes in Sapota (Manilkara achras Millfor sberg) cv. Kalipatti fruits During Growth and Development. Ind. Food. Pack, 41(4): 11-18.

Patel, R.K., Maiti, C.S., Deka, B.C., Deshmukh, N.A., Verma, V.K. and Nath, A. 2015. Physical and biochemical changes in guava (Psidium guajava L.) during various stages of fruit growth and development. Inter. J. of Agric. Envir. and Biotech., 8(1): 7582.

Poongodi V.K.T., Punitha, K. and Banupriya, L. 2013. Drying characteristics and quality evaluation of wood apple (Limonia acidissima L.) fruit pulp powder. Inter. J. of Curr. Tre. Res., 2(1): 147-150.

Randhawa, G.S., Khanna, R.C. and Jain, N.L. 1964. Seasonal changes in fruits and bearing shoots of the grapefruit. Ind. J. of Horti, 21: 21-23.

Ranganna, S. 2010. Handbook of Analysis and Quality Control for Fruit and Vegetable Products, (Tata McGrawHill Education Private Ltd), New Delhi.

Ruffner, H.P., Koblet, W. and Rast, D. 1975. Galacogenesis in the ripening berries of grapes (Vitis vinifera). Vitis, 13(4): 319328.

Saima, Y., Das, A.K., Sarkar, K.K., Sen, A.K.S. and Sur, P. 2000. An antitumor pectic polysaccharide from Feronia limonia L. Inter. J. of Bio. Macromolecules, 27(5): 333-335.

Seeja, E., Edwin, E. and Smita, G. 2005. A comparative pharmacognostical and phytochemical studies on the leaves of Aegle marmelos and Feronia elephant. Plant Archi, 5(2): 549-552.

Shukla, S.K. and Singh, A.K. 2008. Underutilized and Underexploited crops. In: wood apple (Ed. Peter, K.V.). 
New India Publishing Agency Pitam Pura New Delhi, 4: 267-288.

Singh, S.P. and Acharya, P. 1999. Effect of stages of harvesting on physicochemical attributes of phalsa (Grewia subinequalis D.C.). Horti. J., 12(1): 8183.

Singh, S.P., Bhatt, L. and Prasad, M. 2004. Physico-quality changes associated with growth and development of banana (Musa species L.) fruit cv. Dwarf Cavendish. Agri. Sci. Digest, 24(3): 197-199.

Swine, T. and Hills, H.E. 1959. The phenolic constituent of Prunus domestica L. Quantitative analysis of phenolic constituents. J. of Sci. and Agri., 10: 6378.
Tan, S.C. and Lam, P.F. 1985. Effect of gamma irradiation of PAL activity and phenolic compounds in papaya (Carica papaya L.) and mango (Mangifera indica L.) fruit. Asian Food. J., 1: 134136.

Troup, R. S. 1921. The Silviculture of Indian tree. Government of India Publisher, 3: 101-103.

Ulchino, K., Tasuda, Y. and Sakoda, K. 1994. Relation of harvest date and skin colour of fruit quality of loquat 'Magi' during maturation. J. of Japanes. Soci. For Horti. Sci., 63: 484-497.

Zablackis, E., Huang, J., Mullar, B., Darvill, A.G. and Albersheim, P. 1995. Characterization of the cell-wall. Government of India, 69-72.

\section{How to cite this article:}

Awadhesh Kumar and Bhagwan Deen. 2017. Studies on Bio-Chemical Changes in Wood Apple (Limonia acidissima L.) Fruits during Growth and Development. Int.J.Curr.Microbiol.App.Sci. 6(8): 2552-2560. doi: https://doi.org/10.20546/ijcmas.2017.608.302 